\title{
Discussion article: Discourse markers, modal particles, and contrastive analysis, synchronic and diachronic*
}

\section{Elizabeth Closs Traugott}

Stanford University. USA

traugott@stanford.edu

\begin{abstract}
I discuss three issues common to papers in the present issue of CatJL by Aijmer, Bazzanella et al., and Waltereit and Detges. One is modal uses of discourse markers and distinctions between discourse markers and modal particles. The second is evidence provided by the papers for diachronic changes that individual markers underwent; the distinction between grammaticalization and pragmaticalization is considered and challenged. Finally, I raise some issues regarding the methodology of data-selection in contrastive studies.
\end{abstract}

Key words: modality, grammaticalization, pragmaticalization, subjectification, zero-correspondence in translation, writing.

\section{Table of Contents}

\section{Introduction}

2. Discourse markers and modal particles

3. From the diachronic perspective
4. The methodology of data-selection in contrastive studies

5. Some question for further research References

\section{Introduction}

In the original call for papers for this special issue the editor, Maria Josep Cuenca, invited contributions to the analysis of pragmatic markers from a contrastive perspective using parallel corpora. Preference was expressed for analysis of a single marker or a small, coherent group of markers. "The markers should be apposition connectives with a typical (though not necessarily exclusive) turn/sentence initial use. The preferred ones are grammaticalized markers such as well, with very weak propositional content and, thus, ambiguous and polysemic". Therefore all the papers

* Many thanks to the authors, especially Karin Aijmer, Carla Bazzanella, Ulrich Detges and Richard Waltereit, for discussion and for answering my questions about their papers so patiently. Thanks also to Maria Josep Cuenca and Neal Norrick for comments. I am of course responsible for any misinterpretations that remain. 
in this issue of CatJL address polyfunctionality, and aim to tease apart at least some of the functions associated with the markers they select.

My comments concern three of the papers: those by Carla Bazzanella, Cristina Bosco, Alessandro Garcea, Barbara Gili Fivela, Johanna Miecznikowski, and Francesca Tini Brunozzi on "Italian allora, French alors", Karen Aijmer on "The meaning and function of the Swedish discourse marker alltsa", and Richard Waltereit and Ulrich Detges on "Different functions, different histories" of Spanish bien and French bien. The first two papers are contrastive, using translations to provide insights into the discourse markers under investigation. The second is synchronic, the first and third historical. Despite these differences, all three necessarily take written materials as their prime data. "Necessarily" because historical work usually, and certainly in the case of the papers in question, uses texts several hundreds of years old. Such texts are not only written, but for the most part in "literate/schooled" - style, i.e. relatively formal and syntax - rather than clausebased, barring some representations of speech in drama and novels (for discussion see e.g. Tannen 1987, Matthiessen and Thompson 1988). Likewise, translations, even if contemporary, are typically written; if they are spoken, they nevertheless tend to have literate features, cf. simultaneous translations at a United Nations meeting. As Norrick points out in section 4 of his paper, written and spoken, especially everyday spontaneous registers are very different, and should not be compared absent clear recognition of the problems attendant on so doing.

I begin with some comments on distinctions made in the three papers I am discussing with respect to discourse markers and modal particles (section 2). Section 3 explores evidence provided by the papers for changes that the individual markers underwent over time. In section 4 I address some issues concerning data-selection in contrastive studies. Section 5 suggests some questions for further research.

\section{Discourse markers and modal particles}

First, a terminological point. All three papers refer primarily to discourse markers. Aijmer points out that these are, in Fraser's (1996) taxonomy, a subset of pragmatic markers (see also Schiffrin 1987, Norrick This issue of CatJL). Waltereit and Detges refer to pragmatic markers in their first and final sections; for them this is the superordinate term for pragmatic and modal markers (p.c). The distinction between discourse marker and pragmatic marker is not significant for the set of papers I am discussing, but another one, between discourse marker and modal particle is, and it is to this distinction that I now turn.

\subsection{Discourse markers}

Discourse markers have been studied since the mid 1970's from various perspectives. Whatever the approach, the object of analysis is broadly speaking expressions "that function in cognitive, expressive, social, and textual domains" (Schiffrin 2001: 54) and are multifunctional, for example, Italian allora 'then' (Bazzanella et al.), Swedish alltså 'so, thus' (Aijmer), and Spanish bien 'well' (Waltereit and 
Detges). More narrowly defined, they are "sequentially dependent elements which bracket units of talk" (Schiffrin 1987: 31), and deictically "either point backward in the text, forward, or in both directions" (Ibid.: 323). Fraser (1988: 21-22) restricted the deictic relationship further, as "specifying the type of sequential discourse relationship that holds between the current utterance ... and the prior discourse" ("prior discourse" includes contextually inferrable utterances). The study of discourse markers clearly requires focus on communicative as well as cognitive aspects of linguistic knowledge, and on units that are of various sizes, often, but not exclusively, larger than sentences as traditionally studied in grammatical theory (Hansen 1998: 122 refers to "communicative acts" as the relevant functional unit within their scope). In other words, they draw attention to the importance for linguistic theory not only of structure but also of use, for example, of dependency on the speech situation as well as on linguistic expression (co-text). They challenge the notion of the sentence as the prime unit of linguistic analysis, and also draw attention to the importance of interfaces, whether between semantics and pragmatics or between meaning and sound, especially intonation.

The term discourse marker is used in the following ways in the papers under discussion:

a) Waltereit and Detges define discourse markers as units operating at the discourse level, i.e. chunks larger than clause or sentence, and as enabling joint coordination of interaction. Specifically, discourse markers mark moves that negotiate topic-shift, turn-taking, etc.

b) Bazzanella et al. characterize discourse markers as interacting with three domains: interaction, text structure, and cognition, but focus on the second and third domains. With respect to allora/alors, (meta)textual (also called "correlative") uses highlight discourse units, and signal shifts to new topics, etc. The cognitive uses are a subtype of "consequential" meanings: "inferred as a consequence of", and in this sense modal (they often occur in conditional if...then constructions).

c) Aijmer identifies regulation of common ground as the basic function of discourse markers, but points out that there are other subfunctions, including two that she regards as modal: inferential and requests for clarification.

In the early literature on discourse markers, modality was not usually cited as a relevant factor. However, Aijmer (1997) suggested that I think is a "modal particle", and the affinities between discourse markers and "modal" expressions of various types has been a topic of discussion ever since. Three different approaches are exemplified in the three papers on which I am commenting. One approach is to distinguish sharply between discourse markers and modal particles on both formal and discourse functional grounds (see section 2.2. below), as do Waltereit and Detges. Another is to make no difference between the terms, apparently on discourse pragmatic grounds, while recognizing that "formally" clause-internal position is the modal particle position (see the end of Aijmer's section 2). For Aijmer the modal uses are "context-adjusting" with "the function to check every now and 
then that the interactants understand each other (Vaskó and Fretheim 1997: 235)". A third approach, taken by Bazzannella et al., is to show that certain discourse marker uses have epistemic inferential modal values.

The differences may be attributed in part to the fact that the modal functions identified are considerably different in the different languages, or at least are conceptualized in different ways. French bien is conceptualized as adversative, French alors as consequential (both causal in the "world out there" and inferential ("given A, I infer B")), while Swedish alltså is conceptualized as primarily inferential. Another reason for the differences is the extent to which syntax is attended to, and to which the language under investigation has a clearly definable syntactic slot for a particular modal meaning. Waltereit and Detges clearly privilege syntax more than does Aijmer, while the markers that Bazzanella et al. discuss do not appear to have strictly differentiated syntax in their different meanings.

\subsection{Modal particles narrowly defined}

As Waltereit and Detges point out, considerable effort has been put into classifying modal particles in terms of their syntax, especially in Germanic languages (other than English), where they are very type-frequent. "Middle-field" position is held to be of utmost importance in German (cf. Weydt 1969, Abraham 1991). Modal particles have also been discussed in the context of French (Hansen 1998 shows that bien, déja, donc, peut-être and seulement have modal particle properties). In Germanic languages like German and Dutch, and in French what modal particles have in common from a syntactic perspective is that they are fairly rigidly restricted to a language-specific clause-internal position (in abstract syntax). Phonologically they often lack stress, and semantically they often have inferential, epistemic meaning. They are in many cases untranslatable into English, and indeed in this tradition English is said not to have any modal particles (I think, for example, does not meet the criterion of clause-internal position). Examples include (1)-(3): ${ }^{1}$

\section{(1) German}

a. Kommt er denn?

Comes he MP?

'Will he really come/will he come after all?'

b. Gib mir doch den Löffel.

Give me MP the spoon

'Give me the spoon!' (said with irritated intonation)

(Abraham 1991: 333, 340)

1. Abbreviations in this and the following schemas are as follows (in alphabetical order): Adv: adverb; AdvMan: adverb of manner; AdvTPost: temporal posterior adverb; Conseq: consequential; DM: discourse marker; Infer: inferential; MP: modal particle; Par/elab: paraphrastic elaboration; Paraph/recap/cor: non-paraphrastic, recapitulation, correction; ReqClar: question, request clarification. 
(2) Danish

a. Det har jeg da ikke sagt.

That have I MP not said

'I didn't say that.'

b. Det har du sgu da vel ikke gjort!

That have you MP MP MP not done

'You didn't do that!'

(Hansen 1998: 43)

(3) French

a. Ce n'est déja pas mal. That neg-is MP not bad

'That's not bad at all.'

b. Regarde donc où tu vas!

Look MP where you go

'Do look where you are going!'

(Hansen 1998: 41)

Other researchers have a less restricted definition. For example, de Haan (2005: 39) points out that stress may not be a good criterion cross-linguistically, given the English examples in (4) which seem functionally to be modal particles:

(4) a. Affective is $T O O$ a word!

b. There is so a Santa Claus!

(de Haan 2005: 39)

According to de Haan, rigid syntax may not be a criterion either: since modal particles have (semantic) scope over the entire sentence, they may also occur clauseinitially and finally, as in Cantonese. On such a view, distinctions between modal particles and discourse markers become hard to maintain, especially as examples like English too, so are clearly anaphoric and deictic to prior discourse (although not clause-initial).

Waltereit and Detges characterize modal particles as:

a) having a conventionally fixed syntactic scope (which is not specified in their article, but appears to exclude clause-initial position),

b) functioning at the "speech-act level" (presumably the level of the sentence), ${ }^{2}$ and

c) as being highly content-dependent.

2. What the scope of a "speech-act" may be, is however, debatable. While it may be reasonable to think of illocutionary acts as having a clause (or "sentence") in their scope in interactive talk, it is less clear that this is a useful notion for extended (written) texts (see Mey 1993: 183, and his reference to van Dijk's 1977: 215 proposal of a "macro speech act" that is "performed by the utterance of a whole discourse"). 
Modal particles are distinguished from discourse markers primarily in terms of scope: modal particles have fixed scope, whereas discourse markers have variable scope and position because they signal relationships between "chunks" of discourse. We may infer that modal particles in their view do not have connective properties (see Hansen 1998: 42: the "alleged connective force may be a "sideeffect' of the more basic function of MPs"). Waltereit and Detges posit different functions for discourse markers and modal particles, specifically different argumentative orientation (hence they are subject to different speaker motivations in change). In their view discourse markers are used to negotiate "What are we going to do next?" (Waltereit and Detges, p. 72), while modal particles "refer to participants' stance toward speech acts (Waltereit 2001)" (Ibid., p.74), and are polyphonous in the sense of Ducrot (1984), that is, they encode multiple voices. In this case the voices are contesting and adversative.

\subsection{The significance of zero-correspondence}

One of the defining features of modal particles is said to be that they are often deletable, not translated, or even untranslatable into other languages (e.g. Hansen 1998: 44, de Haan 2005: 39). But deletability and non-correspondence in translation are not unique to modal particles. For example, Aijmer (this volume) cites evidence of non-translation of concessive discourse markers in Swedish and Norwegian, despite tendencies for translation to be more explicit than the original text (her section 11). ${ }^{3}$

Aijmer notes that omission of allstå is frequent in her data (41\%) when it is in medial position, i.e. structurally has modal particle function. It does not occur when alltså is in initial position. This is strikingly different from the situation that Bazzanella et al. report. They do not identify structural modal particle uses for allora, but they do find that $17 \%$ of allora in the late thirteenth century Old Italian text Novellino is either not translated into Modern French or translated by a weak connective. They note that non-translation usually occurs when allora is "metatextual", i.e. marks temporal sequence and highlights single discourse units. In its meta-textual/correlative function allora is a clause-peripheral (initial or final) discourse marker. It is possible that this non-correspondence between the Old Italian source and its French translation (and to a lesser extent between contemporary Italian Paso Doble and its translation, where non-translated allora has a consequential function) may be due to redundancy with the "iconic" effect of narrative sequencing that matches actual event sequence.

Aijmer identifies redundancy with other functional cues in the context as a likely context for zero-expression. For example, alltså need not be translated in questions. The redundancy presumably is that questions are modal, seeking epistemic confirmation. Her examples (31) and (32) furthermore imply their answer, as in:

3. Concessives are of course modal, but not structurally modal particles. 
(5) (= Aijmer's (31))

Men du har alltså inga misstankar om brott?

But you have MP no suspicion of foul-play

'But you don't suspect foul play?'

Similarly, Waltereit and Detges illustrate a question in French with a modal particle that "evokes a foregoing assertion by the hearer (E1) to the effect that the corresponding proposition is true" (p. 74):

(6) (= Waltereit and Detges' (27))

C'est bien la première fois que vous êtes en retard?

It's MP the first time that you are in lateness?

'Is it really the first time you are late?'

Since Waltereit and Detges (this volume) interpret modal particles as having "polyphonous semantics" (p. 78), apparently even more so than discourse markers, it might seem surprising that modal particles would be so readily deletable in translation. One might assume that such functions of an item would be translated, while the more pragmatic/procedural ones associated with discourse markers might not be, since the latter arise in context. However, since the contexts for modal particles are dialogic, and the particles serve to mark an assertive speech act in contexts of counter-expectation, the contexts may in fact be redundantly adversative.

Other than redundancy, two other possible reasons for non-correspondence are suggested. Aijmer proposes that absence of translation may also "be a cue to pragmaticalization since it suggests that the meaning of alltså has been weakened" (p. 54). Bazzanella et al. propose that the different functions of Italian allora and French alors is reflected in the non-correspondences, i.e. a reason for non-correspondence may be that speakers of different languages put different weight on cognates. Temporal meanings of allora are more significant in Italian, especially Old Italian, whereas in Modern French alors has a more modal value. Conversely, this difference is further supported by the fact that if a temporal reading is intended, an explicit temporal with restrictive meaning will be chosen.

\section{From the diachronic perspective}

In this section I consider how the diachronic perspectives brought by Bazzanella et al. and Waltereit and Detges, and by Aijmer's largely synchronic perspective contribute to our understanding of how discourse markers arise, and to what extent the markers that have developed from the same lexical source have acquired similar functions in different languages. I also comment on whether they involve grammaticalization or pragmaticalization. 


\subsection{The "paths" of individual markers}

Using the metaphor "path of development" to refer to the schematic stages that a linguist interprets from data, I here outline some hypotheses regarding the historical developments alluded to in the papers. Although many substages would no doubt be identifiable in more detailed historical work, in all cases there appear to be at least two stages: initially an adverb use, then a connective one. In some cases more stages are hypothesized.

Waltereit and Detges discuss in some detail the development of Spanish bien into a discourse marker, and of French bien into a modal particle, both derived from the Latin manner adverb bene 'well'. The historical record shows that in the case of Spanish bien, although pragmatic inferences abound in texts, indisputable examples of discourse marker uses apparently did not arise until the late eighteenth century. In the case of French bien the historical trajectory is less obvious because modal meanings arose very early, but it too seems to have been attested first principally as an adverb (the authors cite an example from Chretien de Troyes' Chevalier de la Charette, c. 1180, example (29)). It appears that in many contexts Old French bien could be interpreted either as an adverb or as a modal particle expressing a counter-argumentative stance; an early example is:

(7) (= Waltereit and Detges' (35))

Bien est de France.

MP is from France

'Indeed he is from France.'

(12 ${ }^{\text {th }}$-13thC Roman de Roncesvaux)

Unambiguous though this appears to be, unfortunately, being cited from the Dictionary Littré, it does not have prior context, and it is verb-second only in abstract structure, so we cannot be sure that it is a modal particle absent more information.

Waltereit and Detges propose that while both discourse markers and modal particles represent types of subjectification, in the sense that their meanings are recruited to encode and regulate attitudes and beliefs (see Traugott 2003), their different developments in Spanish and French are motivated by different argumentative orientations. As mentioned above in section 2.2., according to Waltereit and Detges discourse markers are said to arise out of moves negotiating "What are we going to do next?" while modal particles result from the conventionalization of adversative effects in dialogic exchanges, i.e. "from a dispute about the validity of the assertion of a proposition $p$ ", and "from stereotypical argumentational moves negotiating common ground ("What do I believe that you believe concerning the felicity of my speech act?")" (p. 78). Evidence adduced is from bridging examples, i.e. examples revealing "a speech context in which something inferrable as utterance-meaning from an input sentence-meaning happens also to be true, and thus not defeasible in that context" (Enfield 2005: 318). Consider the following from a text written at the beginning of the thirteenth century: 
(8) (= Waltereit and Detges's (30))

Et mesires Pierres respondi: "Ba!" fist il, “de n'avés vous oï comment Troies "And Mylord Pierre answered: "Ba", he said, "haven't you heard about how Troy

le grant fu destruite ne par quel tor?"

the great was destroyed and in which way this happened?'

"Ba ouil!", fisent li Blak et li Commain, "nous l'avons bien oï dire." " Of course", said Blak and Commain, "we heard clearly / MP about it.", (a 1205 Robert de Clari, La Conquête de Constantinople)

Pierre's negative question is a challenge, therefore adversative, but at the same time it is oriented toward a "yes" answer, so bien can be understood as marking assertion of Blak and Commain's epistemic stance ("surely we heard it"), or as the original adverb ("we heard it clearly"), and both meanings are plausible.

Although Waltereit and Detges include both discourse marker and modal particle meanings for French bien (see their (6)), they do not discuss the discourse marker use, or show how it relates historically to the modal particle use. So, based on their paper, all we can determine is the following:

\section{(9) Span. bien $\mathrm{Adv} \longrightarrow \mathrm{DM}$ in late 18 thC (via sequencing strategy) \\ French bien Adv $\longrightarrow$ MP by 13 thC (via validity checking)}

Bazzanella et al. sketch the development from Latin illa hora 'from that hour' (ablative adverbial phrase) in its posteriority ${ }^{4}$ sense into the Old Italian adverb allo$r a$ and Old French adverb alors, but do not provide specific information about when changes occurred. As adverbs of temporal posteriority, they had relative freedom of position. Given their origin, they were primarily anaphoric. Both were used in clause-initial position to convey

a) meta-textual (or "correlative") meanings that foreground and reorient text,

b) "consequential" or causal meanings.

The latter are of two types: causal in the "world out there" (non-modal, what I will call "external cause") and inferential ("given A, I infer B") (epistemic modal, what I will call "internal cause"). By the time of Novellino (c. 1300), allora was used primarily with temporal, meta-textual and internal causal meanings. Bazzanella et al. draw attention to a couple of examples in Novellino that are translated deductively (their examples (20) and (21)). Both are "over-determined" in the translation, that is, they are translated in such a way as to highlight narratorial shift in

4. In its simultaneity sense, it appears not to have undergone change, but to have persisted into Modern Italian and Modern French (see Bazzanella et al.'s example (22) and its translation). 
perspective, e.g. in (20) Allora li cavalieri ne fecero grande festa 'Then the knights were greatly amused' is translated as:

(10) (= Bazzanella et al.'s 20)

réponse, on le pense bien, qui mit les chevaliers en belle allégresse.

'answer, one assumes, that made the knights greatly amused.'

While Bazzanella et al. say "over-determination of the deductive uses (both for agreeing and disagreeing: ex. 20-21) is evidence for the beginning of a modal shift" (p. 21), there is nothing in the Old Italian text itself to suggest this shift. Rather, the translation appears to support their claim that in Modern French cognitive inferential meanings are more salient than in Old Italian. Indeed, they argue that French alors itself is no longer primarily temporal, but mainly epistemic and inferential. Therefore, more explicit temporal terms are used in the translation, such as ensuite 'and then, afterwards', de nouveau 'anew'.

In the contemporary Italian novel Paso Doble (1995), there are only 20 examples of allora. This makes comparison with Novellino difficult, but it appears that allora is used in most instances with consequential (external cause) and interactional functions; in the French translation three of these uses are not translated, while inferential uses of allora are translated by alors. It appears, then, that developments in Italian and French were similar: the adverbs of temporal posterity gave rise to meta-textual and to external cause meanings, and then to cognitive internal cause meanings. However, Modern Italian speakers use all functions of allora, while Modern French speakers prefer alors in a cognitive, inferential reading. When the changes occurred remains to be determined. We can summarize this as follows (with parentheses indicating marginal uses in the contemporary language):

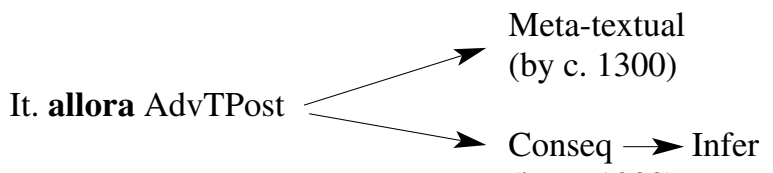

(by c. 1300)

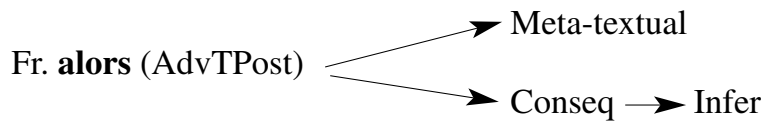

Aijmer notes for Swedish that alltså had an adverb source, but this usage disappeared in the sixteenth century. In Modern Swedish, it has

a) inferential and question (request for clarification) uses that, as discussed above, structurally have modal particle properties (they are clause-internal), and

b) discourse marker uses of two main types that she calls paraphrastic (paraphrase elaboration of the prior utterance), and non-paraphrastic (recapitulating, correcting). Similar usages are found in German, except that non-paraphrastic discourse 
markers frame rather than recapitulate prior text. Interestingly, although Aijmer's paper is primarily synchronic, she hypothesizes a number of developments for Swedish, based on Lehti-Eklund (1990) (see Aijmer, this volume, section 12): ${ }^{5}$

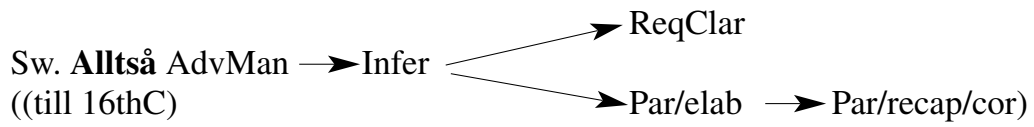

Note that although Aijmer calls the "inferential" uses "discourse markers", they are in fact, as discussed above, modal particles, with a different syntax and semantic scope from the inferential discourse marker functions discussed by Bazzanella et al.

If we put all these hypothesized "paths" together, with attention to structure as well as meaning, the schematic picture is as in (13):

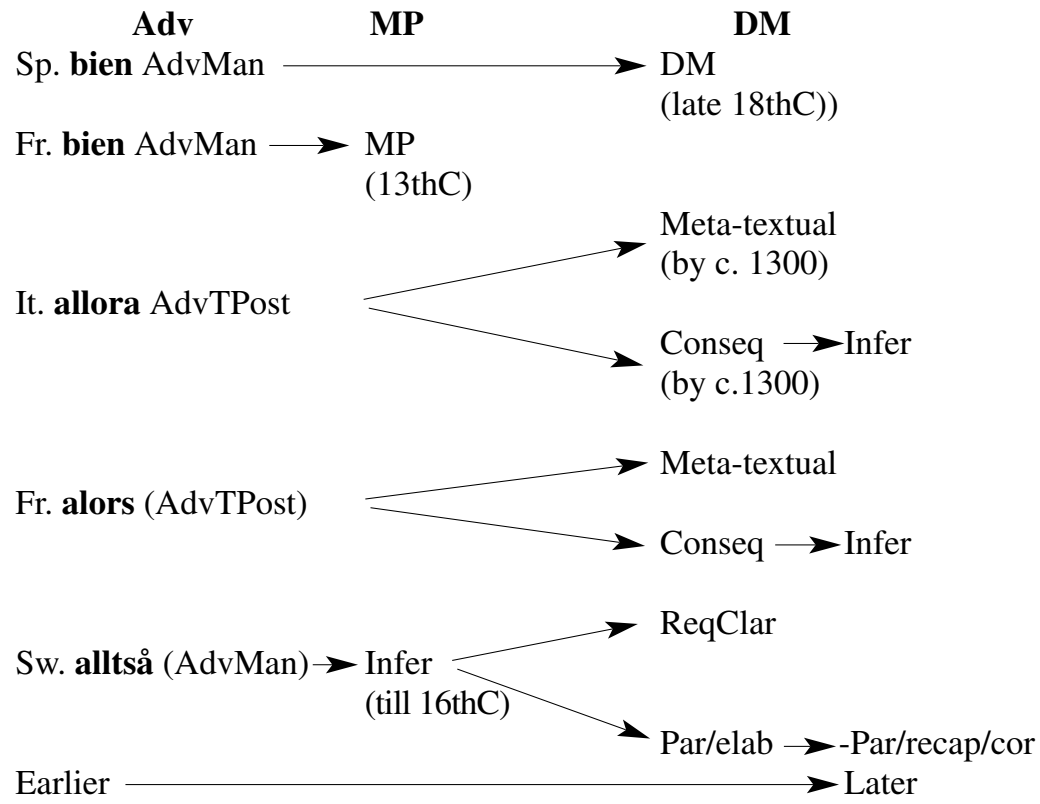

This is a hypothesis which further historical work can test.

5. From the data provided it is not clear that request for clarification is in fact a separate function or stage, since all the examples in the paper are questions either syntactically or phonologically; however, I adapt Aijmer's trajectories as she cites them. Lehti-Eklund (2003: 157) provides the following "grammaticalization path" for alltså:

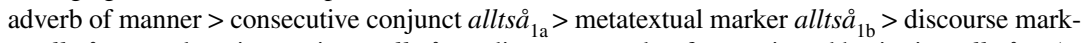

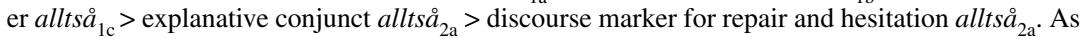
the numeric subscripts suggest, there are two major "steps" in development, the first ( allts $a_{1}$ ) occurring sporadically around 1600 , and the second, discourse marker use (allts $\left.\dot{a}_{2}\right)$ sporadically in the nineteenth century, but not frequently until the twentieth. The alphabetic subscripts specify different syntactic positions. 


\subsection{A comment on pragmaticalization and grammaticalization}

In her paper Aijmer discusses the status of the development of the various functions of alltså in terms of grammaticalization and pragmaticalization. She suggests that "[a]s a result of grammaticalization alltså develops from a manner adverb to a conjunct adverb. 'Pragmaticalization' accounts for the fact that the grammaticalized form of alltså (the conjunct adverb) develops pragmatic meanings as a discourse marker such as request for confirmation, repair and emphasis which are characteristic of later stages of semantic and pragmatic change from a source meaning" (Aijmer, p. 36).

Pragmaticalization, a concept introduced by Erman and Kotsinas (1993) and further developed by Aijmer (see e.g. 1997), is useful in that it draws attention to the fact that some linguistic expressions come, like discourse markers, to have primarily pragmatic function. It is also useful in that it side-steps issues of whether discourse markers are grammatical units or not. For example, since they operate at the level of discourse rather than the clause or sentence, they are often regarded as "extra-grammatical". Likewise, if we focus on the fact that "the discourse units referred to by such markers are not necessarily identical with grammatical units at the sentence-constituent level" (Waltereit and Detges, p. 63), and construe grammaticalization as the development of markers that are "subject to constraints of grammatical nature" (Ibid.), then grammaticalization would not appear to be the relevant change in the development of discourse markers. Nevertheless, Waltereit and Detges conclude that their analysis, which draws on argumentation theory, is not inconsistent with a theory of grammaticalization. In contrast, Aijmer argues that the development of discourse markers is pragmaticalization and not grammaticalization. However, Fraser long ago pointed out that discourse markers have constrained syntactic as well as intonational properties, and claimed that they are therefore "part of the grammar of a language" (Fraser 1988:32), even though they are pragmatic in function. Furthermore, in some languages, their function is expressed by elements that occur in Wackernagel's position (Traugott 1997 [1995]), i.e. after the first constituent of a clause.

Schiffrin points out in her survey of approaches to discourse markers that "the way we identify markers is an outgrowth of how we approach the study of discourse" (Schiffrin 2001: 65). Similarly, the extent to which grammaticalization is considered relevant to the development of discourse markers is an outgrowth of how we approach the study of this type of change. If, with Lehmann (1985, 1995 [1982]), we interpret grammaticalization as a process of loss of autonomy, especially the reduction in form, scope, etc. identified with the development of morphology, then the emergence of discourse markers necessarily cannot be an instance of grammaticalization. Aijmer adopts Lehmann's perspective, one which harks back to Kurylowicz (1976 [1965]) and earlier, when grammaticalization was construed largely as the development of morphology. But unfortunately Lehmann's criteria, especially what he calls "scope reduction" are not supported by his own data. As pointed out in Tabor and Traugott (1998) and in Hopper and Traugott (2003), Lehmann regards nominalization as a case of grammaticalization, and in 
Lehmann (1995 [1982]: 64) treats the English nominal gerund as in the constant reading of magazines as a grammaticalized (reduced) form of the verbal gerund, as in John's constant reading of magazines/John's reading magazines constantly. However, the history was in the reverse order. More recent versions of the hypothesis that grammaticalization entails reduction include Haspelmath's definition of grammaticalization as a change "by which the parts of a constructional schema come to have stronger internal dependencies" (Haspelmath 2002: 26), and Kiparsky's weaker "other thing being equal, the learner prefers "stronger internal dependencies"" (Kiparsky 2006). The "other things being equal" in Kiparsky's view are adjustments when subsystems collapse. They may look like counterexamples to grammaticalization, but in fact they are not, since they optimize a system that is otherwise becoming non-optimal, e.g. when English lost its case inflections, the genitive $-s$ was less than optimal because it was the only inflection, and was realigned (optimized) to clitic status, and when Old English demonstratives were lost, the masculine and feminine personal pronouns were upgraded to referentially independent status, thus optimizing anaphoricity.

Kiparsky's view of grammaticalization depends on a concept of universal grammar and of change arising from language acquisition. But other things may be equal in different ways as well if different assumptions are made, such as that grammar is largely the result of on-line structuring and negotiation, of communication as well as cognition (see e.g. Croft 2001). Discourse markers have helped us rethink the nature of the relationship of use to structure, and of communicative to cognitive aspects of language. They also allow us to rethink the nature of what is "grammatical structure". If we construe grammaticalization as the development of grammatical material, i.e. the material that signals speakers' perspective on the relationship among participants in an event (case), of events to each other and to the time of the speech situation (tense, aspect), and of utterances to each other and the beliefs of speakers and hearers (modal and discourse markers), we can see that discourse markers, like these traditional grammatical markers, typically undergo changes associated with grammaticalization. Lehti-Eklund (2003) concludes that Swedish alltså grammaticalized on the grounds of changes that are:

a) syntactic: reanalysis of the adverb, decategorialization,

b) semantic: generalization, subjectification, intersubjectification, and

c) phonological: reduction.

We can also conclude that the changes undergone not only by alltså but also by allora/alors and bien involve shifts that Himmelmann (2004) has more recently identified as criterial for grammaticalization:

a) host class expansion (increase in co-occurrence with types of constituents, e.g. expansion of temporal allora to main clauses in conditionals),

b) syntactic expansion (increase in syntactic distributional properties, e.g. shifts from clause-internal to clause-initial position), and

c) pragmatic-semantic expansion (the multifunctionality that is the topic of this issue of $($ atJL). 
Furthermore, like traditional cases of grammaticalization, they involve the development of highly frequent routines (see Bybee 2003). Occam's Razor suggests that "pragmaticalization" is unnecessary as a separate type of change-after all, if it is correct that much semantic change, whether lexical or grammatical, involves meaning shifts that arise metonymically out of the flow of speech in interaction (Traugott and Dasher 2002), then some degree of pragmaticalization will be found in any change involving function as well as form, including the development of standard examples of grammaticalization such as auxiliaries. From this perspective discourse markers simply illustrate extreme forms of pragmatic development.

\section{The methodology of data-selection in contrastive studies}

Contrastive analysis using translations is attractive as a source of information about differences in the value of discourse markers and modal particles, as the comments on the differences between Italian allora and French alors reveal. With several of her colleagues (see e.g. Altenberg and Aijmer 2000, Aijmer and SimonVandenbergen 2003, 2006), Aijmer has developed contrastive analysis as a significant tool in pin-pointing multifunctional uses of linguistic units, and their stylistic value (formal, informal, etc.). However, this important enterprise suffers from a paucity of translation data that meets methodological ideals of comparability. In order to carry out useful quantitative as well as qualitative work, ideally one needs to compare a text $\mathrm{A}$ in one language $\mathrm{L} 1$ with a translation $\mathrm{Bt}$ (where ' $\mathrm{t}$ ' designates "translation") in another language L2 (and so on).

Where historical change is concerned, this scenario is more complex, for example, text A1 at an older stage of L1 needs to be compared with A2t at a later stage, as well as texts B1t and B2t in comparable stages of the other language. As Aijmer says, one can also start one's investigation with the translation and work back to the source; in this case the arrows would be reversed or bidirectional. Here I assume the simple case of starting with the original and comparing the target translation. The ideal model would be as follows:

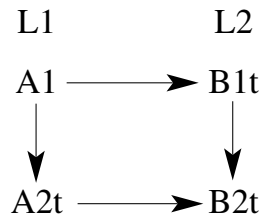

This ideal is, however, very rarely realizable, except in the case of such frequently-translated texts as the Bible, Boethius's Consolation of Philosophy, or the Koran. Even then, there are may be differences in style that may confound the comparison. Furthermore, the works mentioned were often translated from multiple sources and languages (e.g. Chaucer translated his Boece from French as well as Latin versions of Boethius's work). 
As Aijmer and Bazzanella et al. would no doubt be the first to admit, it is not clear exactly how to interpret statistics when the texts are not equivalent, and their length is not normalized. In Bazzanella et al.'s paper, what we have is an Old Italian text, Novellino (A1n) compared with a Modern French translation (B2nt), and also the Modern Italian text Paso Doble (A2pd), compared with a French translation (B2pdt). The two modern translations are also compared, giving a relationship that can be modeled as:

$$
\text { L1 (It.) L2 (Fr.) }
$$

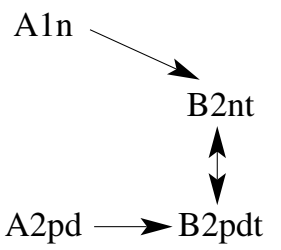

In the case of Aijmer's study, the English-Swedish parallel corpus allowed comparisons between Swedish and their English translations. The results from this comparison are further compared with those from translations of other texts from German into English:

$$
\begin{array}{lc}
\mathrm{L} 1 \\
\mathrm{~A}(\mathrm{Sw} .) \stackrel{\mathrm{L} 2}{\mathrm{~L} 3} \\
\mathrm{C}(\mathrm{Gm} .) \longrightarrow \mathrm{Bt}(\text { Eng })
\end{array}
$$

As a result, although the findings are suggestive, as are the statistics provided, the subtle differences between different uses of discourse markers ultimately remain elusive.

\section{Some questions for further research}

The papers I have discussed raise a number of interesting questions for further research. Here I mention one question raised by each paper:

a) Because Bazzanella et al. have given themselves the task of determining to what extent contrastive analysis can give insights into multifunctional meanings, they naturally put much stock in the translations. It would be worthwhile to study the extent to which alternative translations of the same text provide evidence of the same conclusions about the meanings of discourse markers in 
that text, and hence to be able to develop some measure of the reliability of the translations in revealing nuances in the originals.

b) As Aijmer points out, an important research question is when redundancy is sufficient to allow non-use or non-translation. She cites Hansen (2006: 26) as saying that some markers like French de toute façon 'in any case' "can never be deleted without radically altering the range of possible interpretations of the discourse", and gives the following example from Hansen:

(17) (= Aijmer's (36))

Max a oublié de se rendre à la réunion. De toute façon, le comité 'Max forgot to go to the meeting. In any case, the committee

a décidé d'ajouter cette réunion.

decided to adjourn the meeting.'

The first clause in the example does not provide clues that the dismissive move is up-coming. A question worth investigating is whether non-translation is possibly not so much a function of a particular connective, but rather of the extent to which the prior context provides a sufficiently explicit indication of the speaker's discourse purposes (refutation, elaboration, etc.).

c) Waltereit and Detges' paper reminds us that contexts need to be thought about in terms of strategically and rhetorically manipulated language used creatively to convey meaning, not simply as the discourse that surrounds a language unit or as activated knowledge-structures (activation implies preexistence). An intriguing research question is to what extent creatively adversative discourse (see Schwenter 2000) is a factor in semantic and structural change, and what grammatical domains it is most likely to affect. ${ }^{6}$

Finally, an issue that pertains to all the three papers under discussion, but most especially Aijmer's and my comments here:

d) While there have been questions for several decades about whether discourse markers are analyzable as "grammatical" units, we still need to develop a model that adequately addresses the problem of how to account for units that operate at the discourse level. Functional approaches have successfully questioned the primacy of the sentence over the clause or intonation-unit in spoken discourse, ${ }^{7}$ but the issue of how this pertains to written texts in which the sentence does appear to have some structural validity, is still not clear. ${ }^{8}$ Further study of discourse markers in writing and speech, as well as of their development should help resolve this gap.

6. A different domain under investigation is, for example, the development of ALL-pseudo-clefts (Traugott 2007).

7. See Hansen (1998) for a summary and critique of some of models of language that include discourse.

8. An example relevant to the papers I discuss is the differences Lehti-Eklund (2003: 141) notes in the use of Swedish alltså in speech and writing: "[w]hile its main meaning in the written material is consecutive, there is not a single instances of alltså as a consecutive conjunct in the spoken material”. 


\section{References}

Abraham, Werner (1991). "The grammaticization of the German modal particles". In: Traugott, Elizabeth Closs; Heine, Bernd (eds.). Approaches to Grammaticalization (Typological Studies in Language, 19). Amsterdam/Philadelphia: Benjamins, vol. II: pp. 331-380.

Aijmer, Karin (1997). "I think - an English modal particle". In: Swan, Toril; Westvik, Olaf Jansen (eds.). Modality in Germanic Languages (Trends in Linguistics, Studies and Monographs, 99). Berlin/New York: Mouton de Gruyter, pp. 1-47.

Aijmer, Karin; Simon-Vandenbergen, Anne-Marie (2003). "Well in English, Swedish and Dutch". Linguistics 41: 1123-1161.

Aijmer, Karin; Simon-Vandenbergen, Anne-Marie (eds.) (2006). Pragmatic Markers in Contrast (Studies in Pragmatics). Amsterdam: Elsevier.

Altenberg, Bengt; Aijmer, Karin (2000). "The English-Swedish Parallel Corpus: A resource for contrastive research and translation studies". In: Mair, Christian; Hundt, Marianne (eds.). Corpus Linguistics and Linguistic Theory. Papers from the 20th International Conference on English Language Research on Computerized Corpora (ICAME 20) Freiburg im Breisgau 1999. Amsterdam/Philadelphia: Rodopi, pp. 15-33.

Brinton, Laurel J.; Traugott, Elizabeth Closs (2005). Lexicalization and Language Change (Research Surveys in Linguistics). Cambridge: Cambridge University Press.

Bybee, Joan (2003). "Mechanisms of change in grammaticization: The role of frequency". In: Joseph, Brian D.; Janda, Richard D. (eds.). The Handbook of Historical Linguistics (Blackwell Handbooks in Linguistics). Oxford/Malden, MA: Blackwell, pp. 602-623.

Croft, William (2001). Radical Construction Grammar: Syntactic Theory in Typological Perspective. Oxford: Oxford University Press.

de Haan, Ferdinand (2005). "Typological approaches to modality". In: Frawley, William (ed.), with the assistance of Eschenroeder, Erin; Mills, Sarah; Nguyen, Thao. The Expression of Modality (The Expression of Cognitive Categories, 1). Berlin/New York: Mouton de Gruyter, pp. 27-69.

Ducrot, Oswald (1984). Le dire et le dit. Paris: Minuit.

Enfield, Nicholas J. (2005). "Micro- macro-dimensions in linguistic systems". In: Marmaridou, Sophia; Nikiforidou, Kiki; Antonopoulou, Eleni (eds.), with the assistance of Salamoura, Angeliki. Reviewing Linguistic Thought: Converging Trends for the $21^{\text {st }}$ Century (Trends in Linguistics, Studies and Monographs, 161). Berlin/New York: Mouton de Gruyter, pp. 313-325.

Erman, Britt; Kotsinas, Ulla-Britt (1993). "Pragmaticalization: The case of $b a$ ' and you know". Studier i Modernspråkvetenskap 10: 76-93. Stockholm: Almqvist and Wiksell.

Fraser, Bruce (1988). "Types of English discourse markers". Acta Linguistica Hungarica 38: 19-33.

Fraser, Bruce (1990). "An approach to discourse markers". Journal of Pragmatics 14: 383-395.

Fraser, Bruce (1996). "Pragmatic markers". Pragmatics 6: 167-190.

Fraser, Bruce (1998). "Contrastive discourse markers in English". In: Jucker, Andreas; Ziv, Yael (eds.). Discourse Markers: Description and Theory (Pragmatics and Beyond, New Series, 57). Amsterdam/Philadelphia: Benjamins, pp. 301-326. 
Hansen, Maj-Britt Mosegaard (1998). The Function of Discourse Particles: A Study with Special Reference to Spoken Standard French (Pragmatics and Beyond, New Series, 53). Amsterdam/Philadelphia: Benjamins.

Hansen, Maj-Britt Mosegaard (2006). "A dynamic polysemy approach to the lexical semantics of discourse markers (with an exemplary analysis of French toujours)". In: Fischer, Kerstin (ed.). Approaches to Discourse Particles. Oxford: Elsevier, pp. 21-41.

Haspelmath, Martin (2004). "On directionality in language change with particular reference to grammaticalization". In: Fischer, Olga; Norde, Muriel; Perridon, Harry (eds.). Up and Down the Cline-the Nature of Grammaticalization (Typological Studies in Language, 59). Amsterdam/Philadelphia: Benjamins, pp. 17-44.

Himmelmann, Nikolaus P. (2004). "Lexicalization and grammaticalization: Opposite or orthogonal?". In: Bisang, Walter; Himmelmann, Nikolaus; Wiemer, Björn (eds.). What Makes Grammaticalization - A Look from its Fringes and its Components (Trends in Linguistics, Studies and Monographs, 158). Berlin/New York: Mouton de Gruyter, pp. 19-40.

Hopper, Paul J.; Traugott, Elizabeth Closs (2003) [1993]. Grammaticalization (Cambridge Textbooks in Linguistics). Cambridge: Cambridge University Press, $2^{\text {nd }}$ revised ed.

Kiparsky, Paul (2006). "Grammaticalization ((Uni-)directionality)". Paper presented at the Leverhulme Workshop on Language and Evolution, King's College, London, December $16^{\text {th }}-17^{\text {th }}$.

Kurylowicz, Jerzy (1976) [1965]. "The evolution of grammatical categories". Reprinted in Jerzy Kurylowicz (1976). Esquisses linguistiques. Munich: Fink, Vol. 2, pp. $38-54$.

Lehmann, Christian (1985). "Grammaticalization: Synchronic variation and diachronic change". Lingua e Stile 20: 303-318.

Lehmann, Christian (1995) [1982]. Thoughts on Grammaticalization (LINCOM Studies in Theoretical Linguistics, 1). Munich and Newcastle: LINCOM EUROPA.

Lehti-Eklund, Hanna (2003). "The grammaticalization of alltså and således: Two Swedish conjuncts revisited". In: Cuyckens, Hubert; Dirven, René; Taylor, John R. (eds.). Cognitive Approaches to Lexical Semantics (Cognitive Linguistics Research, 23). Berlin/New York: Mouton de Gruyter, pp. 123-162.

Matthiessen, Christian; Thompson, Sandra A. (1988). "The structure of discourse and 'subordination'”. In: Haiman, John; Thompson, Sandra A. (eds.). Clause Combining in Grammar and Discourse (Typological Studies in Language, 18). Amsterdam/Philadelphia: Benjamins, pp. 275-329.

Mey, Jacob L. (1993). Pragmatics: An Introduction. Oxford/Cambridge, MA: Blackwell. Schiffrin, Deborah (1987). Discourse Markers. (Studies in Interactional Sociolinguistics, 5). Cambridge: Cambridge University Press.

Schiffrin, Deborah (2001). "Discourse markers, meaning, and context". In: Schiffrin, Deborah; Tannen, Deborah; Hamilton, Heidi E. (eds.). The Handbook of Discourse Analysis (Blackwell Handbooks in Linguistics). Oxford/Maldon, MA: Blackwell, pp. 54-75.

Schwenter, Scott A. (2000). "Viewpoints and polysemy: Linking adversative and causal meanings of discourse markers". In: Couper-Kuhlen, Elizabeth; Kortmann, Bernd (eds.). Cause - Condition - Concession - Contrast: Cognitive and Discourse 
Perspectives (Topics in English Linguistics, 33). Berlin: Mouton de Gruyter, pp. 257-281.

Tabor, Whitney; Traugott, Elizabeth Closs (1998). "Structural scope expansion and grammaticalization". In: Giacalone Ramat, Anna; Carruba, Onofrio; Bernini, Giuliano (eds.). Papers from the 7th International Conference on Historical Linguistics (Current Issues in Linguistic Theory, 48). Amsterdam/Philadelphia: Benjamins, pp. 229-272.

Tannen, Deborah (1987). "The orality of literature and the literacy of conversation". In: Langer, Judith A. (ed.). Language, Literacy, and Culture: Issues of Society and Schooling. Norwood, NJ: Ablex, pp. 67-88.

Traugott, Elizabeth Closs (1997) [1995]. "The role of the development of discourse markers in a theory of grammaticalization". Paper presented at ICHL XII, Manchester. http://www.stanford.edu/ traugott/papers/discourse.pdf. Trans. by M. M. Jocelyne Fernandez-Vest as "Le rôle de l'évolution des marqueurs discursifs dans une théorie de la grammaticalization". In: Fernandez-Vest, M. M. Jocelyne; Carter-Thomas, Shirley (eds.). (2003). Structure informationalle et particules nonciatives: Essai de typologie (Grammaire et Cognition, 1 and 2). Paris: L'Harmattan, pp. 295-333.

Traugott, Elizabeth Closs (2003). "From subjectification to intersubjectification". In: Hickey, Raymond (ed.). Motives for Language Change. Cambridge: Cambridge University Press, pp. 124-139.

Traugott, Elizabeth Closs (2007). "On the development of ALL-clefts in English". Paper to be presented at the $10^{\text {th }}$ International Pragmatics Conference, Göteborg, Sweden, July $8^{\text {th }}-13^{\text {th }}$.

Traugott, Elizabeth Closs; Dasher, Richard B. (2002). Regularity in Semantic Change (Cambridge Studies in Linguistics, 97). Cambridge: Cambridge University Press. Van Dijk, Teun A. (1977). Text and Context. London: Longman.

Vaskó, Ildiko; Fretheim, Thorstein (1997). "Some central pragmatic functions of the Norwegian particles altså and nemlig”. In: Swan, Toril; Westvik, Olaf Jansen (eds.). Modality in the Germanic Languages: Historical and Comparative Perspectives (Trends in Linguistics, Studies and Monographs, 99). Berlin: Mouton de Gruyter, pp. 233-292.

Waltereit, Richard (2001). "Modal particles and their functional equivalents: A speechact-theoretic approach". Journal of Pragmatics 33: 1391-1417.

Weydt, Harald (1969). Abtönungspartikel. Bad Homburg: Gehlen. 